J. Asiat. Soc. Bangladesh, Sci. 44(1): 35-51, June 2018

\title{
LAND SUITABILITY ASSESSMENT FOR MAIZE (RABI) CULTIVATION IN COX'S BAZAAR SADAR UPAZILA, COX'S BAZAAR, BANGLADESH
}

\author{
ABDUL HOQUE ${ }^{1}$ AND KHANDAKER TANVIR HOSSAIN ${ }^{2}$ \\ ${ }^{1}$ Department of Geography and Environmental Studies, University of \\ Chittagong, Chittagong- 4331, Bangladesh \\ ${ }^{2}$ Department of Geography and Environment, Jagannath University, \\ Dhaka-1100, Bangladesh
}

\begin{abstract}
Based on the various agro-edaphic and agro-climatic characteristics, the suitability of maize cultivation during winter season has been determined in Cox's Bazaar Sadar Upazila. For this purpose, under the existing climate conditions, considered agro-edaphic factors of various geomorphic units are soil permeability, effective soil depth, available soil moisture, soil reaction $(\mathrm{pH})$, soil salinity, slope etc. Long-term climate attributes of the study area were used to determine the overall climate suitability classes, and the combined land suitability classes for maize (rabi) cultivation have been determined through the adjustment of the agro-edaphic and agro-climatic suitability criteria. Thus, recognized combined land suitability classes for maize ( $r a b i)$ cultivation in the present study area are 'highly suitable', 'suitable', and 'moderately suitable'. A total of 896 hectares land has been found as 'highly suitable' for maize cultivation in Cox's Bazaar Sadar Upazila while approximately 4403 and 11,000 hectares have been identified as 'suitable' and 'moderately suitable', respectively.
\end{abstract}

Key words: Land suitability, Agro-edaphic factors, Agro-climatic criteria, Maize, Cox's Bazaar

\section{Introduction}

Being one of the oldest and most important crops in the world maize (Zea mays L.) is the high yielding grain crop having multiple uses. It is widely cultivated throughout the world, and a greater amount of maize is produced each year than any other grain. Worldwide production of maize was 817 million tonnes in 2009 which is more than rice (678 million tonnes) or wheat (682 million tonnes), and in the year 2012 maize was cultivated in more than 159 million hectares of land worldwide, with a yield of over 5 $\mathrm{t} / \mathrm{ha}$ (Mannaf 2012). The United States produce $40 \%$ of the world's maize harvest while other top producing countries are China, Brazil, Mexico, Indonesia, India, France, Argentina, South Africa and Ukraine (Unnayan Onneshan 2011).

\footnotetext{
${ }^{1}$ Corresponding author: Email: ahoquegeobd@yahoo.com
} 
The expansion of maize cultivation was not successful in Bangladesh during 1960s due to the thrust of the government to promote a rice-based green revolution technology, though its production and yield have experienced an explosive growth in recent years (Rahman and Rahman 2014). For example, the total cropped area of maize has increased from only 2654 ha in 1972 to 197,082 ha in 2012; production from 2249 tonnes to $1,298,000$ tonnes; and yield from $0.85 \mathrm{t} / \mathrm{ha}$ to $6.59 \mathrm{t} / \mathrm{ha}$ during the same period (Rahman and Rahman 2014, BBS 2012). At present, maize ranks 1st among the cereals in terms of yield rate $(6.59 \mathrm{t} / \mathrm{ha})$ as compared to Boro rice $(3.90 \mathrm{t} / \mathrm{ha})$ and wheat $(2.78 \mathrm{t} / \mathrm{ha})$ in Bangladesh (BBS 2012). This is because the Bangladesh Agricultural Research Institute (BARI) has developed seven open pollinated and 11 hybrid varieties of maize (Begum and Khatun 2006, BARI 2008) whose yield potentials are $5.5-7.0 \mathrm{t} / \mathrm{ha}$ and $7.4-12.0$ $\mathrm{t} / \mathrm{ha}$, respectively, and are well above the world average of $3.19 \mathrm{t} / \mathrm{ha}$ (FAO 2011). Maize possesses a wide genetic variability, enabling it to grow successfully in any environment also in Bangladesh, it is grown both in winter and summer seasons, although the former is the dominant one (Rahman and Rahman 2014). This is because the present study attempts to determine the land suitability of maize cultivation during the winter or rabi season growing period in the Cox's Bazaar Sadar Upazila of Bangladesh.

Cox's Bazaar Sadar Upazila, is located within Cox's Bazaar district of the south-eastern region of Bangladesh. Occupying an area of 228.23 sq. km. Cox's Bazaar Sadar Upazila is located between $21^{\circ} 24^{\prime}$ and $21^{\circ} 36^{\prime}$ north latitudes, and $91^{\circ} 59^{\prime}$ and $92^{\circ} 08^{\prime}$ east longitudes (BBS 2012). It is bounded on the north by Chakaria Upazila, on the east by Ramu Upazila, on the south by Ramu Upazila and the Bay of Bengal, and on the west by Moheshkhali Upazila and the Bay of Bengal (SRDI 1996) (Fig. 1). Cox's Bazar Sadar Upazila is rich in natural resources, particularly is abundant with fish. Having a very large, elongated, straight and unbroken sandy beach with hills as the background, Cox's Bazaar attracts a large number of tourists all the year round. At present huge number of residential hotels, motels and cottages have been built to accommodate these tourists and the town is growing very fast. The total enumerated population in Cox's Bazaar Sadar Upazila was 4,59,082 in 2011 while it was counted 3,48,075 during the census conducted in 2001 (BBS 2012).

The overall aim of the present study is to assess the geo-environmental characteristics of the Cox's Bazaar coastal belt of Bangladesh with a view of determining the land suitability in Cox's Bazaar Sadar Upazila for maize (rabi) cultivation. 


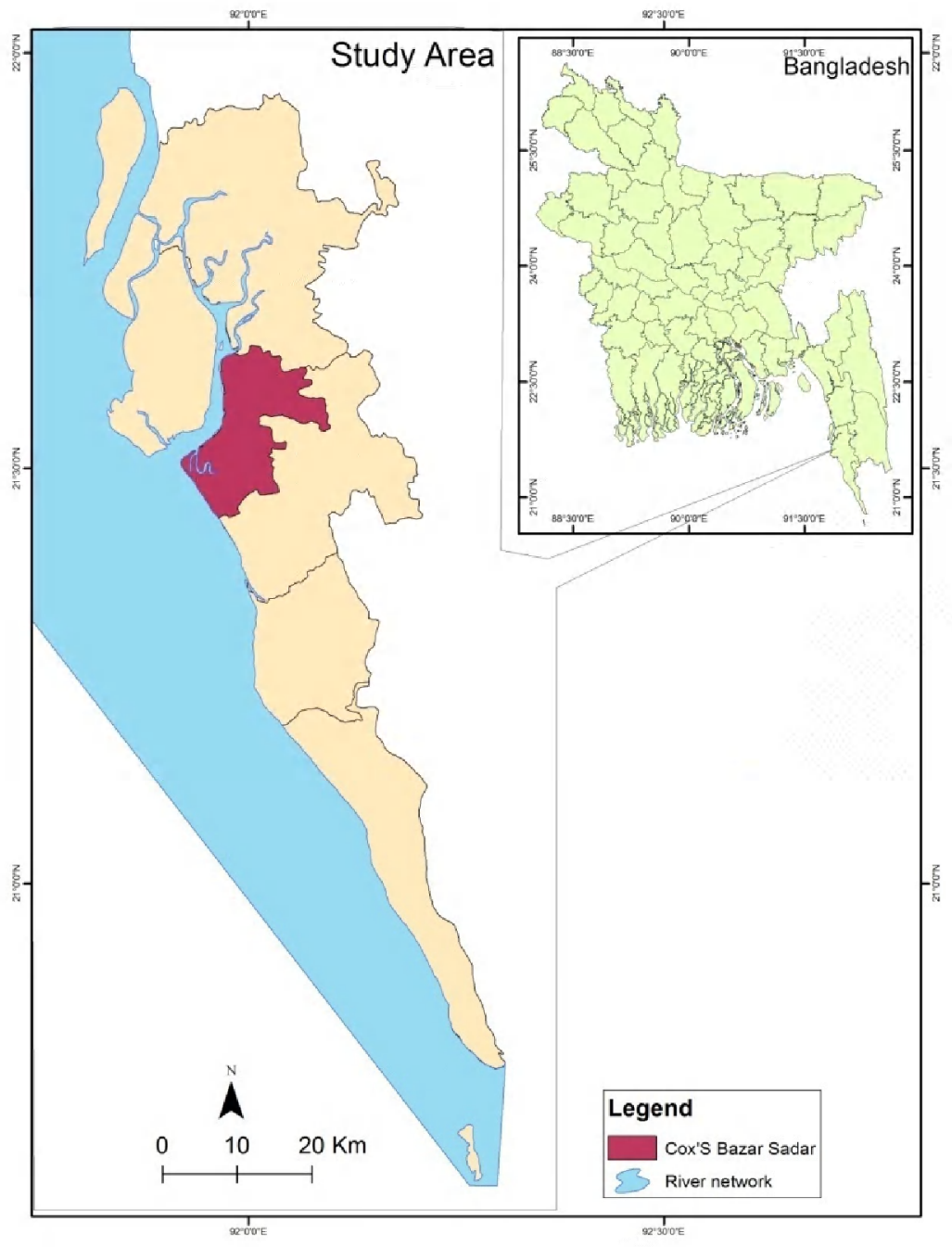

Fig. 1. Location of the study area (Source: Hoque 2017).

The specific objectives of the research for achieving the aim are: To determine the geomorphic unit wise agro-edaphic (e.g., soil permeability, available soil moisture, soil reaction, soil salinity etc.) and agro-climatic (e.g., duration of crop production seasons, standard deviations of their start dates, number of dry days, number of extreme hot and cool days, potential evapotranspiration etc.) criteria of the study area; and to assess the 
land suitability of maize (rabi) cultivation, based on the determined agro-edaphic and agro-climatic criteria of different geomorphic units within the study area.

\section{Materials and Methods}

Identification of major geomorphic units in Cox's Bazaar Sadar upazila: Various geomorphic units of land in the Cox's Bazaar Sadar Upazila have been considered following the geomorphic classification of the Upazila made by (Hoque 2017) during the recent years. In that study, various geomorphic or landform units were initially been identified from $3 \mathrm{D}$ views of aerial photographs which have later been verified by the study of respective satellite imageries (e.g., Landsat TM and ETM + ), topographic sheets and coastal area maps of Bangladesh. Ultimately, identified landform units were confirmed and finalized by a couple of detailed field surveys during the period from October, 2014 to April, 2015. Following the method, a total of 11 geomorphic units had been recognized (Hoque 2017) (Fig. 2) within the study area, out of which 8 units have been taken into consideration for detailed investigation under the present study. Finally, in-depth geo-environmental characteristics (e.g., agro-edaphic and agro-climatic criteria) of various geomorphic units have been determined through a number of detailed field surveys during the period between September, 2015 and May, 2016 for assessing the production suitability of maize ( $r a b i)$, within the study area.

Determining land suitability : Generally crop production capacity of an area significantly depends on agro-edaphic and agro-climatic characteristics of the particular land unit, and therefore those characteristics of considered geomorphic units (Fig. 2) of Cox's Bazaar Sadar Upazila have been used in the present study for maize (rabi) cultivation suitability assessment. The process of assessing crop suitability is to some extent, similar to Hoque (2017) and consistent with the method followed by Bangladesh Agricultural Research Council (BARC 2013). The detailed procedure of determining agro-edaphic and agroclimatic characteristics of various geomorphic units of the study area along with the way of using them to determine agro-edaphic, agro-climatic, and combined maize (rabi) production suitability has been explained. 
Table 1. Land factors with their codes, descriptions, and ratings for major crops in Bangladesh.

\begin{tabular}{|c|c|c|c|}
\hline Factors & Codes & Land factor descriptions & Ratings \\
\hline \multirow{3}{*}{ Soil permeability } & pl & Slow $\left(<12 \mathrm{~cm} \mathrm{~d}^{-1}\right)$ & 1 \\
\hline & $\mathrm{p} 2$ & Moderate $\left(12-305 \mathrm{~cm} \mathrm{~d}^{-1}\right)$ & 2 \\
\hline & p3 & Rapid $\left(>305 \mathrm{~cm} \mathrm{~d}^{-1}\right)$ & 3 \\
\hline \multirow{6}{*}{ Effective soil depth } & $\mathrm{d} 1$ & $<0.25 \mathrm{~m}$ & 1 \\
\hline & $\mathrm{d} 2$ & $0.25-0.60 \mathrm{~m}$ & 2 \\
\hline & $\mathrm{d} 3$ & $0.60-0.90 \mathrm{~m}$ & 3 \\
\hline & $\mathrm{d} 4$ & $0.90-1.22 \mathrm{~m}$ & 4 \\
\hline & $\mathrm{d} 5$ & $>1.22 \mathrm{~m}$ & 5 \\
\hline & d6 & Very firm/hard plow pan & 6 \\
\hline \multirow{4}{*}{ Available soil moisture } & $\mathrm{ml}$ & $<100 \mathrm{~mm}$ & 1 \\
\hline & $\mathrm{m} 2$ & $100-200 \mathrm{~mm}$ & 2 \\
\hline & $\mathrm{m} 3$ & $200-300 \mathrm{~mm}$ & 3 \\
\hline & $\mathrm{m} 4$ & $300-400 \mathrm{~mm}$ & 4 \\
\hline \multirow{3}{*}{ Nutrient satus } & $\mathrm{m} 5$ & $>400 \mathrm{~mm}$ & 5 \\
\hline & $\mathrm{n} 1$ & Low & 1 \\
\hline & $\mathrm{n} 2$ & High & 2 \\
\hline \multirow{5}{*}{ Soil reaction $(\mathrm{pH})$} & al & $<4.5$ & 1 \\
\hline & $\mathrm{a} 2$ & $4.5-5.5$ & 2 \\
\hline & a3 & $5.5-7.3$ & 3 \\
\hline & a4 & $7.3-8.4$ & 4 \\
\hline & a5 & $>8.4$ & 5 \\
\hline \multirow{5}{*}{ Soil salinity } & s1 & 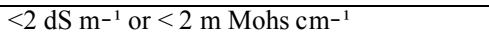 & 1 \\
\hline & s2 & 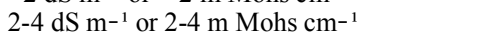 & 2 \\
\hline & s3 & $4-8 \mathrm{dS} \mathrm{m}^{-1}$ or $4-8 \mathrm{~m} \mathrm{Mohs} \mathrm{cm}^{-1}$ & 3 \\
\hline & s4 & $8-15 \mathrm{dS} \mathrm{m}^{-1}$ or $8-15 \mathrm{~m} \mathrm{Mohs} \mathrm{cm}^{-1}$ & 4 \\
\hline & s5 & $>15 \mathrm{dS} \mathrm{m}^{-1}$ or $>15 \mathrm{~m} \mathrm{Mohs} \mathrm{cm}^{-1}$ & 5 \\
\hline \multirow{5}{*}{ Soil consistency } & $\mathrm{t} 1$ & $\begin{array}{l}\text { Not more than slightly firm, slightly sticky, } \\
\text { slightly plastic, hard }\end{array}$ & 1 \\
\hline & $\mathrm{t} 2$ & Firm, very firm, sticky, plastic, hard, very & 2 \\
\hline & & 然, & \\
\hline & $\mathrm{t} 3$ & $\begin{array}{l}\text { Extremely firm, very sticky, very plastic, } \\
\text { extremely hard }\end{array}$ & 3 \\
\hline & t4 & $\begin{array}{l}\text { Organic material to at least } 25 \mathrm{~cm} \text { below } \\
\text { the surface }\end{array}$ & 4 \\
\hline \multirow{6}{*}{ Drainage } & w1 & Well-drained & 1 \\
\hline & w2 & Moderately well-drained & 2 \\
\hline & w3 & Imperfectly drained & 3 \\
\hline & w4 & Poorly drained, surface drains $<15 \mathrm{Nov}$ & 4 \\
\hline & w5 & Poorly drained, surface drains $>15$ Nov & 5 \\
\hline & w6 & Very poorly drained & 6 \\
\hline \multirow{6}{*}{ Depth of inundation } & il & No inundation & 1 \\
\hline & i2 & $<30 \mathrm{~cm}$ & 2 \\
\hline & i3 & $30-90 \mathrm{~cm}$ & 3 \\
\hline & i4 & $90-180 \mathrm{~cm}$ & 4 \\
\hline & i5 & $180-300 \mathrm{~cm}$ & 5 \\
\hline & i6 & $>300 \mathrm{~cm}$ & 6 \\
\hline \multirow{5}{*}{ Flood hazards } & f1 & None & 1 \\
\hline & $\mathrm{f} 2$ & Once in 10 years & 2 \\
\hline & $\mathrm{f} 3$ & Twice in 10 years & 3 \\
\hline & $\mathrm{f} 4$ & $3-4$ times in 10 years & 4 \\
\hline & f5 & 5 times or more in 10 years & 5 \\
\hline \multirow{6}{*}{ Slope } & e1 & $<3$ per cent & 1 \\
\hline & $\mathrm{e} 2$ & 3-8 per cent & 2 \\
\hline & e3 & $8-16$ per cent & 3 \\
\hline & e4 & $16-30$ per cent & 4 \\
\hline & e5 & $30-45$ per cent & 5 \\
\hline & e6 & $>45$ per cent & 6 \\
\hline
\end{tabular}

Source: Modified after BARC 2012, on the basis of the field survey and expert judgments- 2016. 
Agro-edaphic suitability: Involving the desired land and soil distinctiveness with major crops productions in Bangladesh, 11 agro-edaphic factors have been selected (Table 1) in this method. Based on the verification of individual crop productivity demand, the respective level of land and soil quality have been assessed using a 5 degree (0-4) limitations scale (Table 2) for different ranges of agro-edaphic factors. For this purpose, regarding respective crops production, the degrees of limitation with respect to crop requirements of individual land factors were assessed. Accordingly, within different geomorphic units (Fig. 2) of the study area the degrees of limitation of maize (rabi) cultivation for assorted land factors were imposed (Table 3) mainly based on the expert judgments from the National Agricultural Research System (NARS) scientists and other experts who have a wide knowledge base and field experience on crops cultivation. A wide range of literature published by BARC, BRRI, SRDI, UNDP, FAO etc. was also consulted for this purpose. After that, the degree of limitations assigned to land factors under each land face or geomorphic unit was counted. Afterwards, an overall suitability rating for each land face was derived based on the combined limitation ratings using the set of rules on the basis of Zijsvelt's soil-crop suitability model, revised by Brammer in 1985 and further modified by Hussain et al. in 2005 (quoted in BARC 2012). Ultimately, relationships between suitability ratings and number and degrees of limitations were determined to identify ranges of agro-edaphic suitability classes (e.g., S1- very suitable, S2- suitable, S3- moderately suitable, S4- less suitable and NS- not suitable) which were finally used to determine the combined land suitability classes (Table 8) for maize (rabi) cultivations in the study area.

Table 2. Five-degree limitations scale for different ranges of agro-edaphic factors to assess the suitability of various land units for major crops in Bangladesh.

\begin{tabular}{cc}
\hline Numbers & Degree of limitations \\
\hline 0 & No limitation; the most favorable condition for cultivation \\
1 & Slight limitation \\
2 & Moderate limitation \\
3 & Severe limitation \\
4 & Very severe limitation; soil is unsuitable for the particular crop under \\
& consideration at the specified level of management
\end{tabular}

Source: BARC 2013; Field Survey and Expert Judgements- 2016. 
Table 3. Degrees of limitations imposed on different land factors for maize (rabi) cultivation.

\begin{tabular}{cccccc}
\hline Code & $\begin{array}{c}\text { Degree of } \\
\text { limitations }\end{array}$ & Code & $\begin{array}{c}\text { Degree of } \\
\text { limitations }\end{array}$ & Code & $\begin{array}{c}\text { Degree of } \\
\text { limitations }\end{array}$ \\
\hline $\mathrm{p} 1$ & 2 & $\mathrm{a} 3$ & 0 & $\mathrm{i} 1$ & 0 \\
$\mathrm{p} 2$ & 0 & $\mathrm{a} 4$ & 1 & $\mathrm{i} 2$ & 0 \\
$\mathrm{p} 3$ & 2 & $\mathrm{a} 5$ & 2 & $\mathrm{i} 3$ & 1 \\
$\mathrm{~d} 1$ & 3 & $\mathrm{~s} 1$ & 0 & $\mathrm{i} 4$ & 3 \\
$\mathrm{~d} 2$ & 2 & $\mathrm{~s} 2$ & 2 & $\mathrm{i} 5$ & 4 \\
$\mathrm{~d} 3$ & 0 & $\mathrm{~s} 3$ & 4 & $\mathrm{i} 6$ & 4 \\
$\mathrm{~d} 4$ & 0 & $\mathrm{~s} 4$ & 4 & $\mathrm{f} 1$ & 0 \\
$\mathrm{~d} 5$ & 0 & $\mathrm{~s} 5$ & 4 & $\mathrm{f} 2$ & 0 \\
$\mathrm{~d} 6$ & 2 & $\mathrm{t} 1$ & 0 & $\mathrm{f} 3$ & 1 \\
$\mathrm{~m} 1$ & 2 & $\mathrm{t} 2$ & 1 & $\mathrm{f} 4$ & 2 \\
$\mathrm{~m} 2$ & 1 & $\mathrm{t} 3$ & 3 & $\mathrm{f} 5$ & 3 \\
$\mathrm{~m} 3$ & 0 & $\mathrm{t} 4$ & 4 & $\mathrm{e} 1$ & 0 \\
$\mathrm{~m} 4$ & 1 & $\mathrm{w} 1$ & 0 & $\mathrm{e} 3$ & 1 \\
$\mathrm{~m} 5$ & 3 & $\mathrm{w} 2$ & 0 & $\mathrm{e} 4$ & 3 \\
$\mathrm{n} 1$ & 2 & $\mathrm{w} 3$ & 0 & $\mathrm{e} 5$ & 4 \\
$\mathrm{n} 2$ & 0 & $\mathrm{w} 4$ & 0 & $\mathrm{e} 6$ & 4 \\
$\mathrm{a} 1$ & 2 & $\mathrm{w} 5$ & 3 & & \\
$\mathrm{a} 2$ & 1 & $\mathrm{w} 6$ & 4 & & \\
\hline
\end{tabular}

Source: Based on BARC 2013; and Field Survey and Expert Judgements- 2016.

Agro-climatic suitability: A tropical monsoon climate with hot, wet summers and cool, dry winters prevails in Bangladesh, and only those crops that can be grown under these climatic conditions warrant the emphasis of being evaluated for our food security. For agro-climatic zoning, the area wise duration of crop production seasons, standard deviations of their start dates, number of dry days, excessive rainfalls, number of extreme hot and cool days, and potential evapotranspiration (PET) are generally considered in Bangladesh. Accordingly, considering respective climate constraints in a region, the following four precipitations and temperature related determinants are identified in different areas of the country with the view to ensure better planning strategy for various crops production (SRDI 1996):

(a) Duration of pre-kharif transition period, or time frame of uncertain and discontinuous rainfall.

(b) Average duration of rain-fed kharif and rabi crops production periods.

(c) Average number of days with minimum temperature $<15^{\circ} \mathrm{C}$ which is very much important for major rabi crops in particular.

(d) An average number of days with maximum temperature $>40^{\circ} \mathrm{C}$, when the potential evapotranspiration (PET) rate reaches the detrimental level.

Finally, based on the critical analysis of the information related to precipitation, temperature, evapotranspiration, and exhaustion of soil moisture two main crops 
production periods (kharif and rabi) are identified in Bangladesh which is highly adorned by three major climate seasons, viz. pre-monsoon, monsoon, and winter. Thus, three major crops growing periods (viz., pre-kharif transition period, kharif growing period, and rabi growing period) and two major thermal zones (viz., rabi or cool temperature zones, and extreme summer temperature zones) are recognized (BARC 2012) which play a significant role to determine crops agro-climatic suitability of a region.

Climate suitability determination of the study area: From the agro-climatic point of view, maize can be grown with a minimum temperature of $10^{\circ} \mathrm{C}$ and a maximum $30^{\circ} \mathrm{C}$, though the most favorable temperatures for the pollination and quicker growth of maize range from $20-30^{\circ} \mathrm{C}$ (Dewan et al. 1998). The average minimum and maximum temperatures of 12 and $29^{\circ} \mathrm{C}$, respectively, are ideal for successful maize production and it has the capacity to flourish under a wide range of moisture conditions $(500 \mathrm{~mm}-5000 \mathrm{~mm}$ of annual rainfall) (Dewan et al. 1998). However, 1000 - $1500 \mathrm{~mm}$ per year, and 300 - 600 $\mathrm{mm}$ rainfalls during the rabi growing period (October - November to February - March) are optimum for the maize (irrigated) cultivation in Bangladesh (BARC 2012).

Based on the verification of maize (rabi) productivity demand, the degrees of limitation with respect to requirements of individual climate conditions (e.g., temperature, rainfall) were assessed in different parts of the present study area. Alike agro-edaphic suitability determination, the degrees of limitation of maize (rabi) cultivation for respective climate attributes were also selected by the help of expert judgments from the National Agricultural Research System (NARS) scientists and other stakeholders who have a wide knowledge base and field experience on crops cultivation. A wide range of literature published by various organizations (e.g., BARC, BRRI, SRDI, UNDP, FAO etc.) was also consulted for this purpose. Finally, relationships were established among the ranges of prevailing climate attributes (e.g., temperature and rainfall) and respective maize (rabi) production suitability classes (Tables 4 and 5) with respect to the long-term average temperatures and rainfall data (Tables 6 and 7) of the study area. Thus, the overall climate suitability rating (viz. very suitable, suitable, moderately suitable, less suitable and not suitable) of various geomorphic units were determined which were later used for assessing the combined maize (rabi) production suitability classes (i.e., HS, S, MS, SS and NS) (Table 8) of the respective geomorphic units within the study area. 
Table 4. Temperature categories (monthly), ranges and corresponding suitability classes of maize (rabi) production in Bangladesh.

\begin{tabular}{llll}
\hline $\begin{array}{l}\text { Temperature } \\
\text { types }\end{array}$ & Ranges & $\begin{array}{l}\text { Corresponding } \\
\text { suitability }\end{array}$ & $\begin{array}{l}\text { Determined } \\
\text { suitability class for } \\
\text { the study area }\end{array}$ \\
\hline Average & 20 to $<30$ & Very suitable & $\checkmark$ \\
Temperature $\left({ }^{\circ} \mathrm{C}\right)$ & 16 to $<20 ;$ or 30 to $<34$ & Suitable \\
& 14 to $<16 ;$ or 34 to $<38$ & Moderately suitable & \\
& 12 to $<14 ;$ or 38 to $<42$ & Less suitable \\
Average minimum & 11 to $<13$ & Not suitable \\
Temperature $\left({ }^{\circ} \mathrm{C}\right)$ & 9 to $<11 ;$ or 13 to $<16$ & Very suitable \\
& 7 to $<9 ;$ or 16 to $<19$ & Moderately suitable & $\checkmark$ \\
5 to $<7 ;$ or 19 to $<22$ & Less suitable \\
Average maximum & 27 to $<31$ & Not suitable \\
Temperature $\left({ }^{\circ} \mathrm{C}\right)$ & 23 to $<27 ;$ or 31 to $<35$ & Suitable \\
& 19 to $<23 ;$ or 35 to $<39$ & Moderately suitable & $\checkmark$ \\
& 15 to $<19 ;$ or 39 to $<43$ & Less suitable \\
Overall & $<15 ;$ or 43 and above & Not suitable \\
& & Very suitable \\
\hline
\end{tabular}

Source: Prepared on the basis of the expert judgments and literature review in 2016.

Table 5. Ranges of precipitation and corresponding suitability classes of maize (rabi) production in Bangladesh during rabi growing period.

\begin{tabular}{llll}
\hline $\begin{array}{l}\text { Period of } \\
\text { precipitation }\end{array}$ & $\begin{array}{l}\text { Ranges } \\
(\mathrm{mm})\end{array}$ & $\begin{array}{l}\text { Corresponding } \\
\text { suitability }\end{array}$ & $\begin{array}{l}\text { Determined } \\
\text { suitability class for } \\
\text { the study area }\end{array}$ \\
\hline Rabi growing & $300-600$ & Very suitable & $\checkmark$ \\
Period (Oct. - Mar.) & 250 to $<300$; or 601 to 800 & $\begin{array}{l}\text { Suitable } \\
\text { Moderately } \\
\text { suitable }\end{array}$ \\
& 200 to $<250 ;$ or 801 to 1000 & $\begin{array}{l}\text { Less suitable } \\
150 \text { to }<200 ; \text { or } 1001 \text { to } 1200\end{array}$ & Not suitable \\
\hline
\end{tabular}

Source: Prepared on the basis of the expert judgments and literature review in 2016. 
Table 6. Averages of 30 years temperature data during rabi growing period (October March) in Cox's Bazaar Sadar Upazila.

\begin{tabular}{cccccccc}
\hline Temperatures & \multicolumn{5}{c}{ Name of the months covering rabi growing period } & Average \\
\cline { 2 - 6 } & October & November & December & January & February & March & \\
\hline Average $\left({ }^{\circ} \mathrm{C}\right)$ & 27.4 & 24.9 & 21.5 & 20.5 & 22.3 & 25.3 & 23.65 \\
$\begin{array}{c}\text { Average } \\
\text { Minimum }\left({ }^{\circ} \mathrm{C}\right)\end{array}$ & 24.0 & 20.5 & 16.2 & 14.6 & 16.4 & 20.2 & 18.65 \\
$\begin{array}{c}\text { Average } \\
\text { Maximum }\left({ }^{\circ} \mathrm{C}\right)\end{array}$ & 30.9 & 29.3 & 26.9 & 26.4 & 28.2 & 30.5 & 28.70 \\
\hline
\end{tabular}

Source: https://en.climate-data.org/location/56253/Accessed on 01.07.2017

Table 7. Monthly averages of 30 years rainfall data during rabi growing period (October - March) in Cox’s Bazaar Sadar Upazila.

\begin{tabular}{lllllll}
\hline October & November & December & January & February & March & Total \\
\hline $249 \mathrm{~mm}$ & $73 \mathrm{~mm}$ & $20 \mathrm{~mm}$ & $7 \mathrm{~mm}$ & $11 \mathrm{~mm}$ & $22 \mathrm{~mm}$ & $382 \mathrm{~mm}$ \\
\hline
\end{tabular}

Source: https://en.climate-data.org/location/56253/ Accessed on 01.07.2017

Combined suitability determination: At the last stage of the assessment process, in order to get the combined or overall land suitability classes of different geomorphic units for maize (rabi) cultivation, the agro-edaphic and agro-climatic suitability criteria were adjusted on the basis of the rules presented in Table 8 . Finally, the overall or combined land suitability in Cox's Bazaar Sadar Upazila was determined and displayed in the map (Fig. 2) which show the potential areas under different land suitability classes, i.e. highly suitable, suitable, moderately suitable etc. for maize (rabi) cultivation. 
Table 8. Relationship between agro-edaphic, agro-climatic and combined land suitability ratings.

\begin{tabular}{lll}
\hline $\begin{array}{l}\text { Agro-climatic suitability } \\
\text { rating }\end{array}$ & $\begin{array}{l}\text { Agro-edaphic suitability } \\
\text { rating }\end{array}$ & $\begin{array}{l}\text { Combined land suitability } \\
\text { rating }\end{array}$ \\
\hline & S1 (Very suitable) & HS (Highly suitable) \\
VS (Very suitable) & S2 (Suitable) & S (Suitable) \\
& S3 (Moderately suitable) & MS (Moderately suitable) \\
& S4 (Less suitable) & SS (Slightly suitable) \\
& NS (Not suitable) & S (Suitable) \\
& S1 (Very suitable) & MS (Moderately suitable) \\
S2 (Suitable) & SS (Slightly suitable) \\
S (Suitable) & S3 (Moderately suitable) & SS (Slightly suitable) \\
& S4 (Less suitable) & NS (Not suitable) \\
& NS (Not suitable) & MS (Moderately suitable) \\
& S1 (Very suitable) & SS (Slightly suitable) \\
SS (Moderately suitable) & SS (Slightly suitable) \\
& S3 (Moderately suitable) & NS (Not suitable) \\
& S4 (Less suitable) & NS (Not suitable) \\
& NS (Not suitable) & SS (Slightly suitable) \\
& S1 (Very suitable) & SS (Slightly suitable) \\
& S2 (Suitable) & NS (Not suitable) \\
LS (Less suitable) & S3 (Moderately suitable) & NS (Not suitable) \\
& S4 (Less suitable) & NS (Not suitable) \\
& NS (Not suitable) & NS (Not suitable) \\
& S1 (Very suitable) & NS (Not suitable) \\
& S2 (Suitable) & NS (Not suitable) \\
& S3 (Moderately suitable) & NS (Not suitable) \\
& S4 (Less suitable) & NS (Not suitable) \\
\hline NS (Not suitable) & NS (Not suitable) & \\
& & \\
& &
\end{tabular}

Source: Prepared on the basis of BARC 2012; expert judgments of NARS scientists; collated field experiences in 2016.

\section{Results and Discussion}

Various geomorphic units of land within the Cox's Bazaar Sadar Upazila have been adopted following the geomorphic classification of the area by Hoque (Hoque 2017). In that classification, a total of 11 geomorphic units (Fig. 2) were recognized out of which 8 units (e.g., medium high hilly areas, low hills and valley areas, piedmont plain with highland, foothill plain with medium highland, foothill floodplain with medium lowland, tidal floodplain with high and medium highland, tidal floodplain with medium highland, and tidal floodplain with medium high and medium lowland) have been taken into consideration for land suitability analysis under the present study. Considering agroclimatic (e.g., rainfall based crops growing periods, and thermal zones) and agro-edaphic characteristics (e.g., soil permeability, effective soil depth, soil moisture, nutrient status, soil $\mathrm{pH}$, soil salinity etc.) of various landforms the unit wise land suitability of maize 
(rabi) cultivation in the study area have been assessed which are discussed below in details.

Major geomorphic units of Cox's Bazaar Sadar Upazila: Among the identified major geomorphic units Medium High Hilly Area includes around 1,500 hectares areas maximum (900 ha) which are distributed over the eastern part of Eidgaon Union at seven locations. Rest of the areas are located in the southern most part of the Upazila under Jhilonga Union (525 ha) while a tiny piece of land is located in the Pukkhali Union at the north (Fig. 2). Low hills and valley area covers a total of 4,600 hectares land that enfolds approximately $23 \%$ of the Cox's Bazar Sadar Upazila. These lands are scattered over 6 major and a few minor segments of lands in Eidgaon, Patali Machuakhali, Jhilongja, Khuruskhul and Varuakhali Unions, and Cox's Bazaar Pourashava. Piedmont Plain with Highland includes a total of approximately 1900 hectares land covering about $10 \%$ area of the Cox's Bazaar Sadar Upazila and distributed over 10 isolated

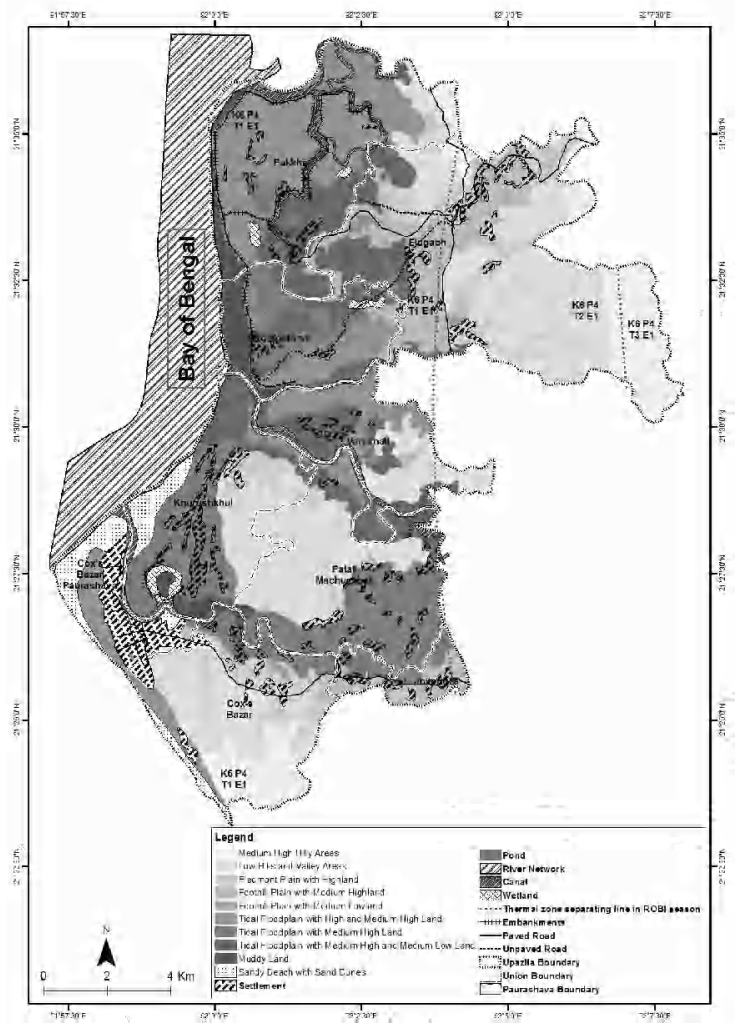

Fig. 2. Map showing various geomorphic units in Cox's Bazaar Sadar Upazila of Cox's Bazaar district (Source: Hoque 2017). 
pieces of lands within Eidgaon, Jhilongja, Patali Machuakhali, Khuruskhul, Varuakhali, and Pukkhali Unions. Almost whole of this geomorphic unit includes agricultural lands containing 74\% highland, 23\% medium highland and a small amount of lowland. Foothill plain with medium highland covers 1180 hectares land which is only $6 \%$ of the total study area and distributed over 6 unions, namely Eidgaon, Jhilongja, Pukkhali, Chaufaldandi and Patali Machuakhali. Maximum of these lands are cultivable medium high land, while the rests are high land with settlements. Foothill plain with medium lowland occupiesonly 45 hectares area maximum of which are located in Jhilongja and Eidgaon Unions. On the other hand, Tidal floodplain with high and medium highland covers approximately 2800 hectares land which is nearly $14 \%$ of the whole study area. This geomorphic unit is separated into 7 segments and distributed over 8 unions of Cox's Bazar Sadar Upazila. More than half (1,545 ha) of these lands are located in the Pukkhali Union while the rests are located in Varuakhali, Choufoldondi, Jhilongja, Patali Machuakhali, Eidgaon, and Khuruskhul Unions (Fig. 2). Tidal floodplain with medium highland contains approximately 2,500 hectares of lands which are divided into 10 pieces and located in Eidgaon, Choufoldondi, Pukkhali, Varuakhali, Patali Machuakhali and Khurushkhul Unions. The whole area under this geomorphic unit contains medium highlands almost all of which are quite cultivable. Furthermore, Tidal floodplain with medium high and medium lowland occupies approximately 2180 hectares of lands which cover roughly $11 \%$ of the present study area. These lands are divided into 6 segments and located mainly in Patali Machuakhali, Khurushkhul, Jhilongja and Choufaldondi Unions (Fig. 2). Entire lands under this category are cultivable except a little area in Cox's Bazaar Pourashava and nearly 50 hectares of settlement areas located in the Choufaldondi Union.

Land suitability of maize (rabi) cultivation in Cox's Bazaar Sadar upazila: From the agro-edaphic point of view, maize can be grown all over the country under a wide range of soil conditions. It grows best on a fine sandy-loam to a heavy clay-loam soil, and from a moderately acidic $(\mathrm{pH}$ 5.0) to a moderately alkaline $(\mathrm{pH} \mathrm{8.5)} \mathrm{soil.} \mathrm{Alike} \mathrm{the} \mathrm{present}$ study area large areas of Bangladesh have mainly loamy soils with a $\mathrm{pH}$ range from 5.5 to 7.0, which is ideal for successful growth and development of maize (Hoque 2017). Moreover, maize has the capacity to thrive under a wide range of moisture conditions (500 - $5000 \mathrm{~mm}$ rainfall/year) which produces a good yield in favorable conditions and gives a reasonably good yield under moisture stress conditions. In fact, being a $\mathrm{C} 4$ cereal crop, maize is more efficient in converting solar energy to dry-matter than most other cereals and is also very efficient in using water (Dewan et al. 1998). However, based on the various agro-edaphic and agro-climatic characteristics, the suitability of maize cultivation during winter or rabi growing period has been determined in Cox's Bazaar Sadar Upazila area under the present study.

Based on the prevailing agro-climatic criteria and surveyed agro-edaphic factors of individual geomorphic units of the study area, land suitability classes for maize (rabi) 
cultivation in Cox's Bazaar Sadar Upazila have been identified. Following the specific rules and adjustment processes (Table 8) to combine the agro-edaphic and agro-climatic suitability classes, the combined or overall land suitability classes of areas under the various geomorphic units of the study area were determined. Accordingly, recognized combined land suitability classes for maize (rabi) cultivation in the present study area are 'highly suitable', 'suitable' and 'moderately suitable', and calculated ranges of overall land suitability ratings for these classes are $1.00-1.25,1.26-1.50$ and $1.51-1.75$, respectively. The study reveals that areas under the geomorphic unit of Foothill plain with medium highland are 'highly suitable' for maize (rabi) cultivation in Cox's Bazaar Sadar Upazila. A total of 896 hectares land has been found under this land suitability class, covering $4.6 \%$ of the study area, which is mainly distributed over Eidgaon (526 ha) and Jhilongja (286 ha) Unions (Fig. 3). The rests of the lands are located in Patali Machuakhali (30 ha), Pukkhali (30 ha) and Choufoldondi (23 ha) Unions, along with a little bit (01 ha) in Cox's Bazaar Pourashava. Approximately 34\% lands (310 ha) under this suitability class are relatively high while the remaining $66 \%$ areas are medium highland. Beyond these, roughly 286 hectares lands under the geomorphic unit of Foothill plain with medium highland are not cultivable which are occupied by settlements and located mainly in the Eidgaon Union (Figs 2, 3). Identified soil classes within 'highly suitable' land suitability class for maize (rabi) cultivation in Cox's Bazaar SadarUpazila are Pahartali, Mirsharai, Ukhia, Muhuri and Bijipur, and maximum of these lands fall under Pahartali (556 ha), Mirsharai (233 ha) and Ukhia (62 ha) soil groups.

On the other hand, areas within the geomorphic units of Tidal flood plain with medium highland (2456 ha), Piedmont plain with highland (1887 ha) and Foothill plain with medium lowland (60 ha) of the study area (Fig. 2) have been identified as 'suitable' for the maize (rabi) cultivation. Covering more than $22 \%$ areas of Cox's Bazaar Sadar Upazila these lands are located in Eidgaon (1572 ha), Varuakhali (554 ha), Choufoldondi (548 ha), Pukkhali (530 ha), Patali Machuakhali (418 ha), Jhilongja (410 ha) and Khuruskul (369 ha).

Maximum of the lands (3321 ha) in this suitability class is medium-high, while 1022 and 60 hectares of lands are high and medium lowland, respectively. Nine distinct soil classes are identified within the areas under this maize ( $r a b i)$ cultivation suitability class among which maximum of the lands fall under Pahartali (1491), Kutubdia (1105), Chakoria (860), Mirsharai (326) and Harbang (245) soil groups. The rests (376 ha) of the lands fall under the soil groups of Badarkhali, Chiringa, Bijipur, and Muhuri. 


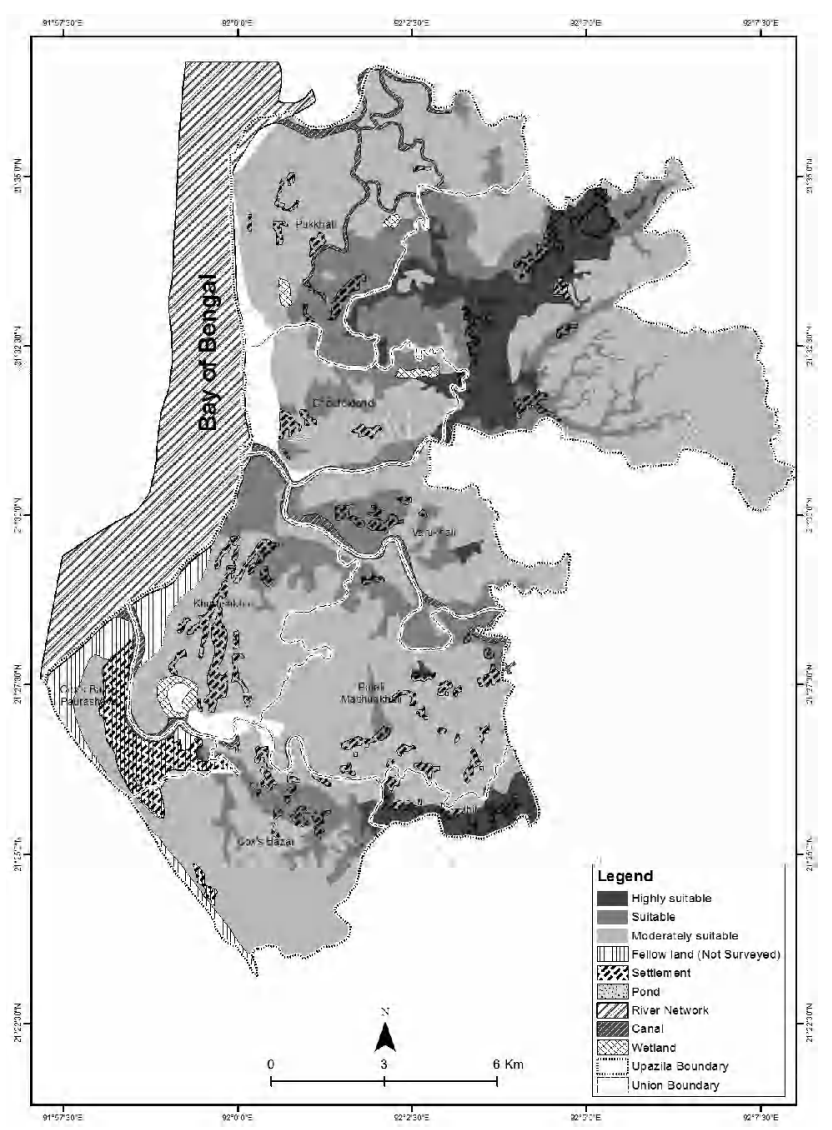

Fig. 3. Land suitability map of Cox’s Bazaar Sadar Upazila for maize (rabi) cultivation.

In addition, having an overall land suitability range $1.51-1.75$, areas within the geomorphic units of medium high hilly areas, low hills and valley areas, tidal flood plain with high and medium high land, and tidal flood plain with medium high and medium low land of the study area (Fig. 2) have been recognized as 'moderately suitable' (Fig. 3) for maize ( $\mathrm{rabi}$ ) cultivation. Covering approximately $55 \%$ of the study area a total of 11021 hectares lands have been found under this suitability class most of which are located in Eidgaon (2782 ha), Patali Machuakhali (2039 ha), Jhilongja (1783 ha), Pukkhali (1757 ha), Khuruskhul (1176), Varuakhali (787) and Choufoldondi (534 ha) Unions (Fig. 3). The rest (163 ha) of the lands are located in Cox's Bazaar Pourashava. The study reveals that approximately 55\% (6022 ha) lands of this suitability class are highland while almost whole of the remaining lands is identified as medium highland (4947 ha). Moreover, more than 15 soil classes have been recognized within these land 
masses out of which nearly $75 \%$ lands fall under Rangamati (2801 ha), Chiringa (1583 ha), Kutubdia (1474 ha), Chakoria (1076 ha), Pahartali (729 ha), Barkal (445 ha) and Subalong (445 ha) soil groups. Identified other soil groups within the areas of this land suitability class are Rangapani (382 ha), Lama (382 ha), Badarkhali (365 ha), Munakhali (332 ha), Mirsharai (310 ha), Dhum (297 ha), Shitakund (148 ha), Tamabil (148 ha) and Harbang (52 ha).

The widespread fertile alluvial soils and subtropical monsoonal climate make a huge area of Bangladesh suitable for maize cultivation. Before independence in 1971, maize was rarely cultivated across Bangladesh except in a few tribal areas of the south-eastern Chittagong Hill Tracts (Mannaf 2012). By the 2009-10 cropping season, it was planted on about 152,226 ha of land with national average grain yields of around $5.83 \mathrm{t} / \mathrm{ha}$, producing well over a million tonnes of maize grain annually (BBS 2010). In fact, with the rapid expansion of poultry industry in the 1990s and 2000s, the demand for maize grain as poultry feed was increased very much in Bangladesh. From 2000 onwards, maize became a lucrative cash crop with a huge and expanding market demand, particularly to the farmers of northern and western Bangladesh (Mannaf 2012).

However, in order to achieve food security at the national level, it is important to encourage farmers of the country to cultivate appropriate crops in their land mainly considering the agro-ecological suitability. During the recent decades, along with the continuously changed climatic conditions of the world, the geo-environmental criteria of the coastal belt of Bangladesh have been changed significantly. This situation may also change the land suitability of various crops cultivations along the coastal areas of Bangladesh which justify the necessity to determine specific crop suitability of different land types at the micro level. In fact, the determination of exact production suitability of various crops in individual land units of coastal agricultural fields will enable to choose appropriate crops for cultivation within the study area which can also be practiced all over the country. This might fulfill the increasing demand for surplus food grains for the continuously growing population in future. Moreover, the appropriate knowledge base on the suitability levels of potential crops in a region can help develop technologies for adaptation of various crops to adverse conditions which may also change the suitability range of specific crops in specific regions. For example, technologies like introgression of flood and salt tolerant genes into different crop varieties might make them somewhat tolerant to flood and salinity in the flood-prone areas or in the saline coastal areas of the country. In addition, varietal development of crops, including management and agronomic manipulation, can offset the impact of hazards like high or low temperatures, floods, salinity, etc. on the yield.

Thus, the local level outcomes of the research work like the present study to determine crop suitability of lands for various crops, including maize varieties, will enable the country to develop a sustainable agriculture planning to ensure food security for the next generation. 
Land suitability assessment for maize cultivation

\section{References}

BARC, 2012. Land Suitability Assessment and Crop Zoning of Bangladesh, Bangladesh Agricultural Research Council, Dhaka.

BARC, 2013. Land Suitability based Crops Zones (Bhumir Upazugita Bhittik Fasal Anchal, in Bengali), Bangladesh Agricultural Research Council, Dhaka.

BARI, 2008. UdvabitaKrishiprojukti 2006-2007 (in Bengali). Bangladesh Agricultural Research Institute, Gazipur, Bangladesh.

BBS, 2010. Statistical Pocket Book of Bangladesh. Bangladesh Bureau of Statistics, Statistics Division, Ministry of Planning, Government of the People's Republic of Bangladesh, Dhaka.

BBS, 2012. Yearbook of Agricultural Statistics of Bangladesh 2012. Bangladesh Bureau of Statistics, Ministry of Planning, Government of Bangladesh, Dhaka.

Begum, M. and F. Khatun 2006. Present Status and Future Prospect of Hybrid Maize in Bangladesh. Training on Hybrid Maize Seed Production Technology 20 - 21 September 2006 Training Manual. Development of Hybrid Maize Research Project (GOB), Plant Breeding Division, Bangladesh Agricultural Research Institute, Gazipur, Bangladesh.

Climate-Data.Org. Climate: Cox's Bazar. https://en.climate-data.org/location/56253/ (Accessed July 1, 2017).

Dewan, S.F.K., M.A. Salam, and A.A. Mondal, 1998. Prospects and Challenges of Expanding Maize Production in Bangladesh. International Maize and Wheat Improvement Center (CIMMYT), Bangladesh.

FAO. 2011. FAOSTAT. Food and Agricultural Organization of the United Nations, Rome, Italy.

Hoque, A. 2017. Geo-Environmental Characteristics and Land Suitability Assessment for Aus Rice (Rupa-Ufshi and Bona-Local) Cultivation in Cox's Bazaar SadarUpazila of Bangladesh. Oriental Geographer 58(1 \& 2), in press.

Hussain, S.G., M.A.H. Chowdhury and M.A. Iqbal 2005. Report on Updating of Edaphic and Agroclimatic Suitability Rules for Selected Crops of Bangladesh. Submitted to CIMMYT/BARC Bangladesh Country Almanac Project.

Mannaf, M. 2012. An Economic Study on Maize Production and its Impact on Food Security in Selected Areas of Bogra District.Unpub. M. S. Thesis. Bangladesh Agricultural University, Mymensingh.

Rahman S. and M.S. Rahman 2014. Exploring the potential and performance of maize production in Bangladesh. Int. J. Agric. Manag. 3: 99-106.

SRDI 1996. Land and Soil Resource Utilization Guide(Bhumi O Mrittika Sampad Bebohar Nirdeshika, in Bengali), Cox's Bazaar Sadar Thana, Cox's Bazaar District.series. 159, Soil Resource Development Institute, Dhaka, Bangladesh.

Unnayan Onneshan. 2011. Food prices, food security and the marginalized. Bangladesh Economic Update 2(5): 2-19. 